International Journal of Life Sciences
Available online at http://sciencescholar.us/journal/index.php/ijls
Vol. 3 No. 2, August 2019, pages: $41 \sim 51$
e-ISSN: 2550-6986, p-ISSN: 2550-6994
https://doi.org/10.29332/ijls.v3n2.309

\title{
Effect of Cod Liver Oil Supplementation in Commercial Feed on Reproductive Organs Weight and Ovarian Follicles Size of Local Rabbits
}

\author{
(1) crossinati \\ Ni Gusti Ayu Manik Ermayanti a, Ida Bagus Made Suaskara b, Iriani Setyawati c, Ni Made Rai Suarni d, \\ I Gusti Ayu Manik Widhyastini e
}

Article history: Received 09 December 2018, Accepted: 30 April 2019, Published: 15 August 2019

\section{Correspondence Author ${ }^{\text {a }}$}

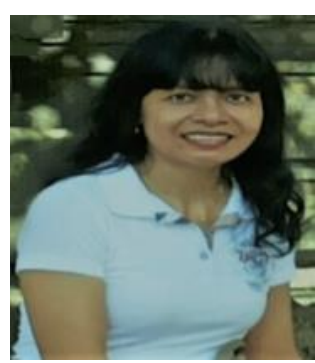

Keywords

cod liver oil;

fatty acid;

local rabbit;

ovary;

reproduction;

\begin{abstract}
This study aimed to determine the effect of cod liver oil supplementation in commercial feed on reproductive organs weight and ovarian follicles size of local rabbits. The experimental design used was Completely Randomized Design with four feed treatments, namely commercial feed without supplementation of cod liver oil (CLO) as control (P0), commercial feed supplemented by 3\% CLO (P1), 4.5\% CLO (P2), and 6\% CLO (P3). Each treatment consisted of ten rabbits as replication and treatment were given to rabbits from aged 4 to 6 months. The parameters observed were the weight of the reproductive organs, namely the ovaries, fallopian tubes, uterus and the size of the ovarian follicles, namely primary, secondary, tertiary and preovulatory follicles of local rabbits. The results showed that various levels of cod liver oil supplementation in commercial feed differed significantly $(\mathrm{P}<0.05)$ to the weight of the reproductive organs and the size of the ovarian follicles of local rabbits. It can be concluded that cod liver oil supplementation at $4.5 \%$ level in commercial feed capable increase the reproductive organs weight and ovarian follicles size of local rabbits.
\end{abstract}

e-ISSN: 2550-6986, p-ISSN: 2550-6994@ Copyright 2019. The Author. SS Journals Published by Universidad Técnica de Manabí. This is an open-access article under the CC BY-SA 4.0 license (https://creativecommons.org/licenses/by-sa/4.0/) All rights reserved.

a Udayana University, Denpasar, Indonesia

b Udayana University, Denpasar, Indonesia

c Udayana University, Denpasar, Indonesia

d Udayana University, Denpasar, Indonesia

e Nusa Bangsa University, Bogor, Indonesia 


\section{Contents}

Abstract

1. Introduction

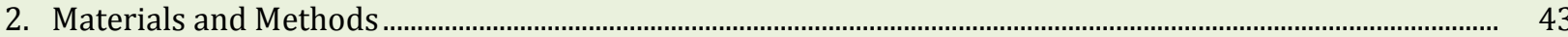

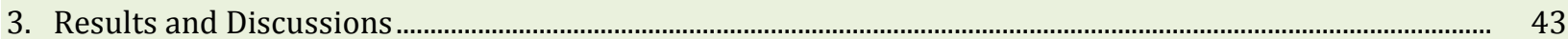

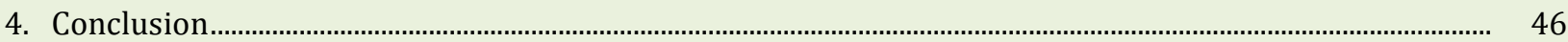

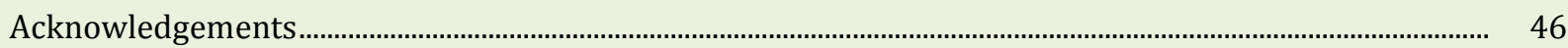

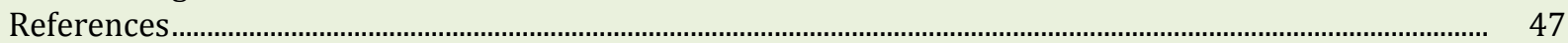

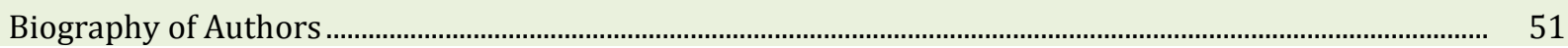

\section{Introduction}

In the female rabbit, the ovaries, oviducts, and the uterus are paired organs, similar to the case in other placental mammal species. The ovaries of rabbits are small, flattened ovoid organs, lying in the right and left lateral pelvic cavity (Popesko et al., 1990; Capello, 2005). The surface of rabbit ovary is covered by a single layer of epithelium. A substantial basement membrane (tunica albuginea) separates the surface cells from the underlying ovarian tissue divided into the inner medulla and outer cortex, which consists of follicles and stroma (Zitny et al., 2004). Beneath the ovaries is the oviduct, made up of the duct, the ampulla and the isthmus (Lebas et al., 1997). The uterus is a complete paired organ (not partially paired as in most of the other placental mammal species). It is bicornuate with 2 cervixes, which open directly and separately into an elongated vagina. The mesometrium (broad uterine ligament) is usually filled with fat, especially in overweight or obese rabbits (Popesko et al., 1990; Capello, 2005). Female rabbits are classified as induced or reflex ovulatory because ovulation takes place after mating (Heape, 1905; Friedman, 1929; Spies et al., 1997; Harkness et al., 2010); hence, rabbits do not have a regular estrous cycle (Harkness et al., 2010). Ovulation occurs 10-13 hours after mating then there is no estrus cycle, but rather a period of receptivity occurring every 5-6 days (Popesko et al., 1990; Capello, 2005).

Nutrition is one of the environmental factors that influence hormonal profile and consequently, reproductive and productive performance of animals (Meshreky \& Metry, 2000; Chiericato et al., 2001; Meshreky \& Shaheed, 2003; Meshreky et al., 2007). Fish oil is a source of long-chain polyunsaturated fatty acids (PUFA). PUFA supplements (particularly n-3 PUFAs in fish oil) are promoted for general health reasons (Wathes et al., 2007). PUFAs must be provided by the diet, since it in vivo synthesis is not possible due to the absence of proper enzymes. PUFA a-linolenic acid (ALA) is necessary for numerous processes, including growth, reproduction, vision, and brain development (Gurr et al., 2002; Ermayanti et al., 2016; Nuriyasa et al., 2018). The result of a study reporting the benefits of fish oil on male and female reproductive performance has been largely undertaken and obtained highly variable results. Cod liver oil supplementation up to $4.5 \%$ could increase testosterone levels and the quality of spermatozoa of local rabbit epididymis (Ermayanti et al., 2016), fish oil diet positively affect testes developments and spermatogenesis in the goat (Adibmoradi et al., 2012), fed a diet supplemented with LNA (n-3) can increase estradiol during the follicular phase in cows (Robinson et al., 2002), supplementation of n-3 PUFA rich fish oil significantly increased the number of pre-ovulatory follicles and ovulation rate in goat (Mahla et al., 2017), dietary PUFAs are known to mediate a broad range of actions in reproductive tissues including effect on membrane fluidity, intra-cellular cell-signalling cascades and susceptibility to oxidative injury (Wathes et al., 2007), change in the composition of dietary fatty acids not only modifies fatty acid composition in the blood plasma but also of the reproductive tissues including, follicular fluid, cumulus cells and the oocytes (Ferguson \& Leese, 1999; Zeron et al., 2002; Bilby et al., 2006; Childs et al., 2008; Fouladi-Nashta et al., 2009; Wonnacott et al., 2010), which can directly influence the competence of oocytes for further development and/or fertility (Wonnacott et al., 2010; Petit et al., 2001). Fatty acids are also precursors for prostaglandins and progesterone synthesis and therefore play an important role in the regulation of normal reproductive function (Abayasekara \& Wathes, 1999; Mattos et al., 2000). Polyunsaturated fatty acids (PUFAs) play a significant role in increasing the number (Lucy et al., 1991) and size of ovarian follicles (Zeron et al., 2002), level of LH (Lucy et al., 1991), and progesterone in follicular fluid (Ryan et al., 1992), regulation of ovulation, CL function (Abayasekara \& Wathes, 1999; Mattos et al., 2000) and pregnancy rate (Bellows et al., 1999). 
Nutrition is related to fertility and fertility is an important factor for successful fertilization. Many studies have reported the effect of fish oil on fertility in several animal models. Furthermore, whether cod liver oil supplementation is able to increase fertility in rabbits before mating, a study is conducted that aims to determine the effects of cod liver oil supplementation on the weight of reproductive organs weight and ovarian follicles size in local rabbits.

\section{Materials and Methods}

\section{Animal}

The animal used is 40 female local rabbits aged 4 months with an average body weight of 2000.60 to 2100.15 g. Rabbits were obtained from Riang Gede Village, Tabanan Regency, Bali. Animals were kept in enclosures of individual battery systems. They were kept under a controlled light-darkness cycle (12 h light; $12 \mathrm{~h}$ darkness). Air temperature in the cage was $27.05^{\circ} \mathrm{C}$ and the air humidity in the enclosure was 75.4.

\section{Administration of feed}

The feed used is commercial feed pellets for rabbits. Commercial feed constituents are yellow corn, bran, soybean meal, molasses, and palm oil. Forty mature female local rabbits divided into four feeding treatments, i.e. commercial feed without supplementation by cod liver oil (P0) as control, commercial feed supplemented by 3\% (P1), $4.5 \%$ (P2), and 6\% (P3) of cod liver oil. Each treatment consisted of ten rabbits as replication and the treatment is given for two months (from the age of rabbit 4 to 6 months).

\section{Reproductive organs weight}

At the end of the study, all the rabbits were killed and then dissected for reproductive organs collection, namely the ovaries, fallopian tubes, and uterus. Before being weighed, the ovaries were washed with $0.9 \% \mathrm{NaCl}$ then dried with filter paper.

\section{Histological ovary}

The ovary is fixed in NBF solution and histological sections $(5 \mu \mathrm{m})$ were serially mounted and stained with hematoxylin and eosin (Alturkistani et al., 2016). The processing of the ovary was made at Veterinary Research Center Denpasar Bali. Furthermore, the histology observations were conducted at the Faculty of Mathematics and Natural Sciences of Udayana University Denpasar Bali. All sections were observed. The ovarian follicles were measured with ocular micrometer calibrated on the binocular microscope. The initiation of primordial follicles growth starts a series of morphological changes leading to subsequent stages of follicular development - the primary and secondary follicles (preantral), tertiary and finally, the preovulatory follicles (antral) (Ross et al., 1995).

\section{Data Analysis}

The data obtained was to analyze statistically using one-way ANOVA and Duncan's Multiple Range Test (DMRT) was used to analyze statistical differences between groups.

\section{Results and Discussions}

The results of the statistical analysis of the effect of cod liver oil in commercial feed on reproductive organs weight and size ovarian follicles size of local rabbits can be seen in Table 1 and Figure 1.

Ermayanti, N. G. A. M., Suaskara, I. B. M., Setyawati, I., Suarni, N. M. R., \& Widhyastini, I. G. A. M. (2019). Effect of cod liver oil supplementation in commercial feed on reproductive organs weight and ovarian follicles size of local rabbits. International Journal of Life Sciences, 3(2), 41-51. https://doi.org/10.29332/ijls.v3n2.309 
Table 1

The effect of cod liver oil in commercial feed on reproductive organs weight and ovarian follicles size of local rabbits

\begin{tabular}{lllll}
\hline & P0 & P1 & P2 & P3 \\
\hline $\begin{array}{l}\text { Body weight (g) } \\
\text { Reproductive organs }\end{array}$ & $2515.00 \mathrm{a}$ & $2515.02 \mathrm{a}$ & $2811.13 \mathrm{~b}$ & $2811.12 \mathrm{~b}$ \\
weight (g) & & & & \\
$\quad$ Ovaries & $0.13 \mathrm{a}$ & $0.14 \mathrm{a}$ & $0.18 \mathrm{~b}$ & $0.17 \mathrm{~b}$ \\
$\quad$ Fallopian tubes & $0.25 \mathrm{a}$ & $0.25 \mathrm{a}$ & $0.30 \mathrm{~b}$ & $0.30 \mathrm{~b}$ \\
$\quad$ Uterus & $4.62 \mathrm{a}$ & $4.63 \mathrm{a}$ & $4.71 \mathrm{~b}$ & $4.70 \mathrm{~b}$ \\
$\begin{array}{l}\text { Ovarian follicles size } \\
(\mu \mathrm{m})\end{array}$ & & & & \\
$\quad$ Primary & $7.30 \mathrm{a}$ & $7.32 \mathrm{a}$ & $12.73 \mathrm{~b}$ & $12.71 \mathrm{~b}$ \\
$\quad$ Secondary & $25.25 \mathrm{a}$ & $25.26 \mathrm{a}$ & $33.23 \mathrm{~b}$ & $33.22 \mathrm{~b}$ \\
$\quad$ Tertiary & $50.41 \mathrm{a}$ & $50.42 \mathrm{a}$ & $87.08 \mathrm{~b}$ & $192.12 \mathrm{~b}$ \\
$\quad$ Preovulatory & $100.00 \mathrm{a}$ & $100.02 \mathrm{a}$ & $192.10 \mathrm{~b}$ & $192.10 \mathrm{~b}$ \\
\hline
\end{tabular}

The values followed by different letters in the same row show significantly different results $(\mathrm{P}<0.05), \mathrm{P} 0=0 \%$ (control), P1=3\% CLO, P2=4.5\% CLO, P3=6\% CLO

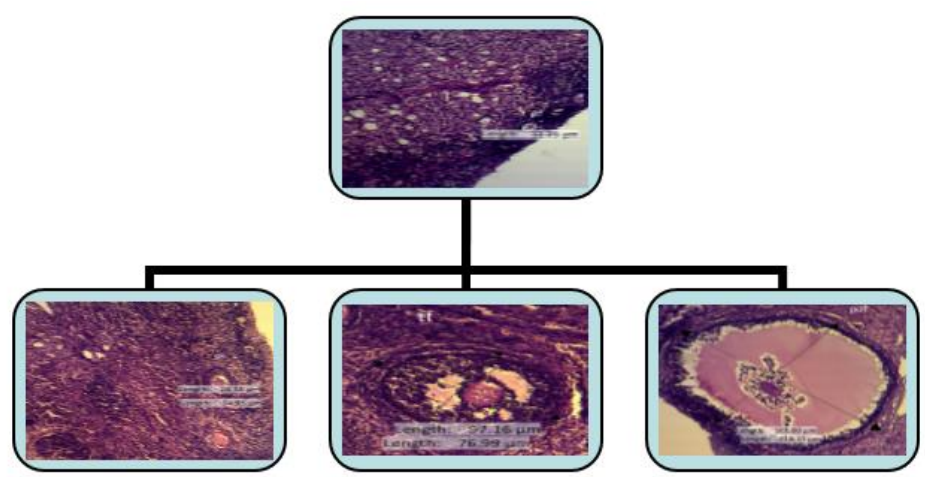

Figure 1. Histological ovary of local rabbits (4.5\% CLO), primary follicles (pf), secondary follicles (sf), tertiary follicles (tf), preovulatory follicles (pof). Stained by H\&E technique. x10.

The effect of cod liver oil supplementation in commercial feed on reproductive organs weight of local rabbits (Table 1). The weight of the reproductive organs is significantly different $(\mathrm{P}<0.05)$ to various levels of fish oil supplementation in commercial feed. The rabbit in the group P1 (3\% CLO) were not significantly different $(\mathrm{P}>0.05)$ from the group without CLO (control). The rabbit in the P2 (4.5\% CLO) and P3 (6\% CLO) groups was significantly different $(\mathrm{P}<0.05)$ from the group without CLO (control). However, the rabbit in the group P2 $(4.5 \%$ CLO) were not significantly different ( $>0.05)$ from group P3 (6\% CLO). This shows that the higher the level of supplementation of fish oil in commercial feed can no longer increase the weight of the reproductive organs. The highest of reproductive organs weight was found in the group P2 (4.5\% CLO). This indicated that rabbits in the group P2 $(4.5 \%$ CLO) had the most influence on the weight of the reproductive organs of local rabbits.

Increasing growth of local female rabbits will be followed by increasing body weight and weight of the reproductive organs, namely the ovary, fallopian tube, and uterus. The occurrence of an increase in the weight of ovary in this study, probably caused by increased estrogen secretion by ovarian follicles. In this study, the rabbits in the group $\mathrm{P} 2(4.5 \%$ CLO) produced the highest increase in body weight and reproductive organs weight. This show, rabbits in the group P2 (4.5\% CLO) had reached puberty with the presence of estrus and mating behavior. Therefore rabbits in group P2 (4.5\% CLO) are ready to mate first and are likely to have the best fertility compared to other groups. 
The ovary is the main reproductive organ in female animals, because it functions as an exocrine organ that produces eggs/ovum and as endocrine organs that secrete female sex hormones, namely estrogen, and progesterone. An estrogen is a group of steroid compounds, named for their importance in the estrous cycle and functioning as the primary female sex hormone. It is also a main reproductive hormone affecting growth, development, maturation, and functioning of the reproductive tract as well as the sexual differentiation and the behavior (Balthazart et al., 2009). Progesterone plays an important role in the regulation of normal reproductive function (Abayasekara \& Wathes, 1999; Mattos et al., 2000). In cows, fed n-3 can increase estradiol concentrations in the follicular phase (Robinson et al., 2002). Supplementation of $4 \%$ fish oil in feed can increase the weight of young rabbits (Kowalska \& Bielanski, 2007). In general, female rabbits reach puberty (i.e. the onset of sexual receptivity and ovulation) at around 14 weeks of age (Hulot et al., 1982; Rommers et al., 2001), although the age at first mating depends upon the breed of rabbit (Harkness et al., 2010). Different feeding systems (ad libitum vs restrictive) will affect reproductive performance in rabbit (Rommers et al., 2001) and some research recommended that breeding begin when the female rabbit reaches about $75 \%$ of its adult weight (Gosalves et al., 1994).

The effect of cod liver oil supplementation in commercial feed on the size of ovarian follicles of local rabbits (Table 1). The size of the ovarian follicles is significantly different $(\mathrm{P}<0.05)$ to various levels of fish oil supplementation in commercial feed. The rabbit in the group P1 (3\% CLO) were not significantly different $(\mathrm{P}>0.05)$ from the group without CLO (control). The rabbit in the P2 (4.5\% CLO) and P3 (6\% CLO) groups was significantly different $(\mathrm{P}<0.05)$ from the group without CLO (control). However, the rabbit in the group P2 $(4.5 \%$ CLO) were not significantly different ( $>0.05)$ from group P3 ( $6 \%$ CLO). This shows that the higher the level of supplementation of fish oil in commercial feed can no longer increase the size of the ovarian follicles. The highest of ovarian follicles size was found in the group P2 (4.5\% CLO). This indicated that rabbits in the group P2 (4.5\% CLO) had the most influence on the size of the ovarian follicles of local rabbits. The effect of cod liver oil supplementation in commercial feed on the histological ovary of local rabbits (Figure 1). Figure 1 taken is the most representative image for group P2 (4.5\% CLO). The size of ovarian follicles from primary follicles to preovulatory follicles in group P2 (4.5 CLO) is larger than P0 (control), P1 (3\% CLO) and P3 (6\% CLO) groups.

In this study, rabbits in the group P2 produced the highest ovarian weight, so it was the possibility of rabbits in the group P2 had the highest follicular size as well compared to other groups. The size of the follicles in the group P2 is primary $(12.73 \mu \mathrm{m})$, secondary $(33.23 \mu \mathrm{m})$, tertiary $(87.08 \mu \mathrm{m})$, and preovulatory $(192.10 \mu \mathrm{m})$ follicles. This show, in the group P2 occurs the development of follicles in the ovary. Folliculogenesis reaches its peak in the form of mature and ovulating preovulatory follicles. This only takes place after the animal reaches puberty. Without mature follicles, signs of estrus will not be seen. This is related to harmonious interactions between the ovaries, pituitary, and hypothalamus.

In female animals, fertility is related to follicular development (folliculogenesis) (Leung \& Adashi, 2004) and it is affected by endocrinology (Paris et al., 2009) and nutrition (Chavatte-Palmer et al., 2014). Nutritional factors influence hypothalamic-pituitary function and therefore gonadotrophin profiles, directly through effects of nutrients or metabolic hormones such as insulin acting on target organs or through changes insensitivity of these organs to estradiol, progesterone and other hormonal feedback mechanism (Rhind, 1992; Muzvondiwa et al., 2011). Lower planes of nutrition delayed the onset of puberty by inhibiting maturation of the endocrine system (Patterson et al., 1992). Follicular development is thought to be supported by the growth of 5 to 10 follicles on each ovary at any one time. Once follicles reach an ovulatory size, they secrete estrogens in increasing amounts and rabbits show sexual receptivity for a period of time. When those follicles degenerate, secretions of estrogen decline and females rabbits become non receptive (Harcout-Brown, 2002). Likewise, results of others have shown that receptive rabbits had more large follicles and a higher concentration of estradiol in the follicular fluid than those of no receptive rabbits (Lefèvre \& Caillol, 1979).

Ovarian function in rabbits is not well understood. Unlike South American camelids (i.e., induced ovulating species in which follicular wave activity has been well documented), the pattern of follicle development in rabbits has not been established. Unlike most other mammals, the formation, activation, and development of ovarian follicles occurred entirely postnatally in rabbits, with primordial follicle assembly presumably completed between 2 and 4 weeks of age (Hutt et al., 2006). With the onset of puberty, follicles reached ovulatory status and were related to sexual behavior. For instance, some authors have indicated that follicles with a diameter $>1.8 \mathrm{~mm}$ were present only in receptive females (Lefèvre \& Caillol, 1979). However, there is no clear understanding of the relationship between follicle diameter and ovulatory capability in rabbits.

Ermayanti, N. G. A. M., Suaskara, I. B. M., Setyawati, I., Suarni, N. M. R., \& Widhyastini, I. G. A. M. (2019). Effect of cod liver oil supplementation in commercial feed on reproductive organs weight and ovarian follicles size of local rabbits. International Journal of Life Sciences, 3(2), 41-51. https://doi.org/10.29332/ijls.v3n2.309 
Preovulatory follicles were also referred to as those $>800$ to 900 um in diameter (Kranzfelder et al., 1984). Others have reported that preovulatory follicles are those that are $>1.5 \mathrm{~mm}$ or $>2 \mathrm{~mm}$ in diameter (Parkes, 1931; Hunzicker-Dunn et al., 1979; Marongiu \& Gulinati, 2008). Continuous growth and regression of follicles appear to occur in receptive rabbits and investigators in an early study suggested that follicles able to ovulate remain for about 7 to 10 days and then regress (Hill \& White, 1933). Follicular development is thought to be supported by the growth of 5 to 10 follicles on each ovary at any one time. Once follicles reach an ovulatory size, they secrete estrogens in increasing amounts and rabbits show sexual receptivity for a period of time. When those follicles degenerate, secretions of estrogen decline and females rabbits become non receptive (HarcoutBrown, 2002). Likewise, the results of others have shown that receptive rabbits had more large follicles and a higher concentration of estradiol in the follicular fluid than those of nonreceptive rabbits (Lefèvre \& Caillol, 1979). Additionally, the ability to ovulate in response to mating was suggested to differ between receptive (accepted mating) and nonreceptive rabbits (refused to mate and were subjected to assisted mating); and $12 \mathrm{~h}$ post-mating, ovulations were detected in $4 / 6$ vs $0 / 4$ rabbits, respectively (Boumahdi-Merad et al., 2011). Findings from others (Hulot et al., 1988) have suggested that failure to ovulate in rabbits may be caused by a lack of discharge of LH rather than to a lack of mature follicles in the ovaries.

Alpha-linolenic acid (ALA; C18:3) is the dietary precursor for the long-chain omega-3 PUFAs (Brenna et al., 2009). It plays an important role in folliculogenesis, developmental competence of oocyte (Moallem et al., 2013), fertilization rate and embryo quality (Thangavelu et al., 2007). As ALA is produced by the ovarian follicles and the amount of ALA increases as the ovarian follicles enlarge (Veshkini et al., 2015); a role of specific unsaturated fatty acids like ALA may be speculated in the oocyte maturation and/or follicular growth. In fact, ALA has been shown to improve the fertility rate in both cattle and sheep by improving folliculogenesis and fertilization rate in vivo (Moallem et al., 2013). When supplemented in the in vitro maturation medium it was reported to regulate the molecular mechanism leading to increased number of MII stage oocytes and improved their subsequent development into early embryos in both cattle (Fouladi-Nashta et al., 2009; Marei et al., 2009) and sheep (Ghaffarilaleh et al., 2014). The supplementation of fish oil (rich with omega 3 fatty acids) improved oocyte quality leading to enhanced blastocyst development and further supported by increased luteal function from the ovary which increased embryo survival and subsequent reproductive performance of sows (Smits, 2010).

Orally-treated rabbit does with sunflower oil (rich in omega 6) or linseed oil (rich in omega 3 ) had the similar impact of PGF2 $\alpha$ ( $0.5 \mathrm{mg}$ dinoprost, a synthetic analog of PGF2 $\alpha$ ) on increasing blood PG profile and decreasing blood P4 and this effect provided the opportunity to increased secretion of gonadotropin hormones from the pituitary and secretion estrogen from the ovary through inhibiting the effect of P4 on gonadotropin release (Elkomy \& El-Speiy, 2015). E2 hormone is necessary for influencing the follicular growth and production of the mature ovum. Estradiol stimulates uterine secretion of PGF2 $\alpha$ (Thatcher et al., 1994). Furthermore, E2 can increase the sensitivity of the CL to PGF2 $\alpha$, thus causing more complete regression of the CL (Howard et al., 1990). That dietary PUFA supplementation can modify the plasma fatty acid profile and prostanoid synthesis. The significant of these modifications vary according to the type of polyunsaturated fat and the ratio of n-6:n-3 fatty acid. On the other hand, PGF2 $\alpha$ reduced the production of P4 because PUFA converted to PGF that caused an increase PGF concentration in the plasma with a reduction of the P4 synthesis (Amira et al., 2011). The follicular phase begins after luteolysis and ends at ovulation. Gonadotropins, FSH, and LH, released from the anterior pituitary, stimulate antral follicles to produce E2 (Smits, 2010).

\section{Conclusion}

It can be concluded that cod liver oil supplementation at 4.5\% level in commercial feed capable increase the reproductive organs weight and ovarian follicles size of local rabbits.

\section{Acknowledgments}

This work was supported by the Research Fund provided by the Directorate of Research and Community Service at the Directorate-General for Research and Development of the Ministry of Research, Technology and Higher Education also to thank Institutes of Research and Community Service Udayana University. 
References

Abayasekara, D. R. E., \& Wathes, D. C. (1999). Effects of altering dietary fatty acid composition on prostaglandin synthesis and fertility. Prostaglandins, Leukotrienes and Essential Fatty Acids (PLEFA), 61(5), 275-287. https://doi.org/10.1054/plef.1999.0101

Adibmoradi, M., Najafi, M. H., Zeinoaldini, S., Ganjkhanlou, M., \& Yousefi, A. R. (2012). Effect of dietary soybean oil and fish oil supplementation on blood metabolites and testis development of male growing kids. Egyptian Journal of Sheep and Goat Sciences, 65(1240), 1-15.

Alturkistani, H. A., Tashkandi, F. M., \& Mohammedsaleh, Z. M. (2016). Histological stains: a literature review and case study. Global journal of health science, 8(3), 72. https://dx.doi.org/10.5539\%2Fgjhs.v8n3p72

Amira, A.K., Zuki, Abu, B., Goh, Y.M., \& Noordin, M.M. (2011). Effect of n-3andn-6fatty acid supplementation on fetal, gestation and parturition in pregnant Sprague Dawley rats. Afr. J. Biotechnol. 10, 7109-7116.

Balthazart, J., Cornil, C. A., Charlier, T. D., Taziaux, M., \& Ball, G. F. (2009). Estradiol, a key endocrine signal in the sexual differentiation and activation of reproductive behavior in quail. Journal of Experimental Zoology Part A: Ecological Genetics and Physiology, 311(5), 323-345. https://doi.org/10.1002/jez.464

Bellows, R. A., Grings, E. E., Simms, D. D., Geary, T. W., \& Bergman, J. W. (2001). Effects of feeding supplemental fat during gestation to first-calf beef heifers. The Professional Animal Scientist, 17(2), 81-89. https://doi.org/10.15232/S1080-7446(15)31602-8

Berbar, A., Belabbas, R., Theau-Clement, M., Bolet, G., Brown, P. J., \& Kaidi, R. (2011). A comparative study on the follicular dynamics between sexually receptive and non-receptive algerian female rabbits after mating. http://www. europeanjournalofscientificresearch. com/.

Bilby, T. R., Block, J., Do Amaral, B. C., Sa Filho, O., Silvestre, F. T., Hansen, P. J., ... \& Thatcher, W. W. (2006). Effects of dietary unsaturated fatty acids on oocyte quality and follicular development in lactating dairy cows in summer. Journal of Dairy Science, 89(10), 3891-3903. https://doi.org/10.3168/jds.S0022-0302(06)724328

Brenna, J. T., Salem Jr, N., Sinclair, A. J., \& Cunnane, S. C. (2009). $\alpha$-Linolenic acid supplementation and conversion to n-3 long-chain polyunsaturated fatty acids in humans. Prostaglandins, leukotrienes and essential fatty acids, 80(2-3), 85-91. https://doi.org/10.1016/j.plefa.2009.01.004

Capello, V. (2005). Surgical techniques for neutering the female pet rabbit. Exotic DVM, 7(5), 15-21.

Chavatte-Palmer, P., Dupont, C., Debus, N., \& Camous, S. (2014). Nutritional programming and the reproductive function of the offspring. Animal Production Science, 54(9), 1166-1176. https://doi.org/10.1071/AN14470

Chiericato, G. M., Rizzi, C., Boiti, C., \& Canali, C. (2001). A study on the effect of feeding restriction on the plasma hormonal response of Grimaud prepubertal does. Rivista di Coniglicoltura (Italy).

Childs, S., Hennessy, A. A., Sreenan, J. M., Wathes, D. C., Cheng, Z., Stanton, C., ... \& Kenny, D. A. (2008). Effect of level of dietary n-3 polyunsaturated fatty acid supplementation on systemic and tissue fatty acid concentrations and on selected reproductive variables in cattle. Theriogenology, 70(4), 595-611. https://doi.org/10.1016/j.theriogenology.2008.04.002

Elkomy, A. E., \& El-Speiy, M. E. (2015). Polyunsaturated fatty acids combined with equine chorionic gonadotropin to enhance reproductive performance in aged rabbit does. Italian Journal of Animal Science, 14(1), 3535. https://doi.org/10.4081/ijas.2015.3535

Ermayanti, N. G. A. M., Oka, I. G. L., Mahardika, I. G., \& Suyadnya, I. P. (2016). Free testosterone level and quality of cauda epididymis sperm of local rabbit that given commercial feed supplemented by cod fish liver oil. International Research Journal of Engineering, IT \& Scientific Research, 2(3), 1-8.

Ferguson, E. M., \& Leese, H. J. (1999). Triglyceride content of bovine oocytes and early embryos. Reproduction, 116(2), 373-378. https://doi.org/10.1530/jrf.0.1160373

Fouladi-Nashta, A. A., Wonnacott, K. E., Gutierrez, C. G., Gong, J. G., Sinclair, K. D., Garnsworthy, P. C., \& Webb, R. (2009). Oocyte quality in lactating dairy cows fed on high levels of n-3 and n-6 fatty acids. Reproduction, 138(5), 771-781.https://doi.org/10.1530/REP-08-0391

Friedman, M. H. (1929). The mechanism of ovulation in the rabbit: I. The demonstration of a humoral mechanism. American Journal of Physiology-Legacy Content, 89(2), 438-442. https://doi.org/10.1152/ajplegacy.1929.89.2.438

Ghaffarilaleh, V., Fouladi-Nashta, A., \& Paramio, M. T. (2014). Effect of $\alpha$-linolenic acid on oocyte maturation and embryo development of prepubertal sheep oocytes. Theriogenology, 82(5), 686-696. https://doi.org/10.1016/j.theriogenology.2014.05.027

Ermayanti, N. G. A. M., Suaskara, I. B. M., Setyawati, I., Suarni, N. M. R., \& Widhyastini, I. G. A. M. (2019). Effect of cod liver oil supplementation in commercial feed on reproductive organs weight and ovarian follicles size of local rabbits. International Journal of Life Sciences, 3(2), 41-51. https://doi.org/10.29332/ijls.v3n2.309 
Gosálvez, L. F., Alvariño, J. M. R., Estavillo, S., \& Tor, M. (1994). Adelanto del inicio de la vida reproductiva de la coneja, mediante estímulo alimenticio. In XIX Simposio de cunicultura: Silleda, 27 y 28 de mayo de 1994 (pp. 149-154). Asociación Española de Cunicultura (ASESCU).

Gurr, M. I., Harwood, J. L., \& Frayn, K. N. (2002). Lipid biochemistry (Vol. 409). Oxford: Blackwell Science.

Harcout-Brown, F. (2002). Textbook of Rabbit Medicine, Elsevier Health Sciences, Oxford.

Harkness, J. E., Turner, P. V., VandeWoude, S., \& Wheler, C. L. (2010). Harkness and Wagner's biology and medicine of rabbits and rodents. John Wiley \& Sons.

Heape, W. (1905). Ovulation and degeneration of ova in the rabbit. Proceedings of the Royal Society of London. Series B, Containing Papers of a Biological Character, 76(509), 260-268. https://doi.org/10.1098/rspb.1905.0019

Hill, M., \& White, W. E. (1933). The growth and regression of follicles in the oestrous rabbit. The Journal of physiology, 80(2), 174.

Howard, H. J., Scott, R. G., \& Britt, J. H. (1990). Associations among progesterone, estradiol-17 $\beta$, oxytocin and prostaglandin in cattle treated with hCG during diestrus to extend corpus luteum function. Prostaglandins, 40(1), 51-70. https://doi.org/10.1016/0090-6980(90)90056-2

Hulot, F., Mariana, J. C., \& Lebas, F. (1982). L'établissement de la puberté chez la lapine (Folliculogenèse et ovulation). Effet du rationnement alimentaire. Reproduction Nutrition Développement, 22(3), 439-453.

Hunzicker-Dunn, M., Jungmann, R. A., \& Birnbaumer, L. (1979). Hormone action in ovarian follicles: Adenylyl cyclase and protein kinase enzyme systems. In Ovarian Follicular Development and Function (pp. 267-304). Raven Press New York.

Hutt, K. J., McLaughlin, E. A., \& Holland, M. K. (2006). Primordial follicle activation and follicular development in the juvenile rabbit ovary. Cell and tissue research, 326(3), 809-822.

Kowalska, D., \& Bielanski, P. (2007). Effect of dietary fish oil supplement on rearing performance of young rabbits and quality of their meat. Polish Journal of Food and Nutrition Sciences, 57 (3 [A]).

Kranzfelder, D., Korr, H., Mestwerdt, W., \& Maurer-Schultze, B. (1984). Follicle growth in the ovary of the rabbit after ovulation-inducing application of human chorionic gonadotropin. Cell and tissue research, 238(3), 611620.

Lebas, F., Coudert, P., Rouvier, R., \& De Rochambeau, H. (1997). The Rabbit: husbandry, health, and production. Rome: Food and Agriculture organization of the United Nations.

Lefèvre, B., \& Caillol, M. (1978). Relationship of estrous behaviour with follicular growth and sex steroid concentration in the follicular fluid in the domestic rabbit. In Annales de Biologie Animale Biochimie Biophysique (Vol. 18, No. 6, pp. 1435-1441). EDP Sciences.

Lucy, M. C., Staples, C. R., Michel, F. M., \& Thatcher, W. W. (1991). Energy balance and size and number of ovarian follicles detected by ultrasonography in early postpartum dairy cows. Journal of dairy science, 74(2), 473482. https://doi.org/10.3168/jds.S0022-0302(91)78194-0

Mahla, A. S., Chaudhari, R. K., Verma, A. K., Singh, A. K., Singh, S. K., Singh, G., ... \& Krishnaswamy, N. (2017). Effect of dietary supplementation of omega-3 polyunsaturated fatty acid (PUFA) rich fish oil on reproductive

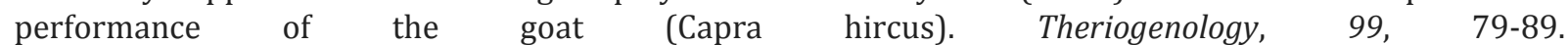
https://doi.org/10.1016/j.theriogenology.2017.05.023

Marei, W. F., Wathes, D. C., \& Fouladi-Nashta, A. A. (2009). The effect of linolenic acid on bovine oocyte maturation and development. Biology of Reproduction, 81(6), 1064-1072. https://doi.org/10.1095/biolreprod.109.076851

Marongiu, M. L., \& Gulinati, A. (2008). Ultrasound evaluation of ovarian follicular dynamics during early pseudopregnancy as a tool to inquire into the high progesterone $(\mathrm{P}+)$ syndrome of rabbit does. In Proceedings of the 9th World Rabbit Congress (pp. 393-398).

Mattos, R. S taples CR and Thatcher WW (2000) Effects of dietary fatty acids on reproduction in ruminants. Review of Reproduction, 5, 38-45.

Meshreky, S. Z., \& Metry, G. H. (2000). Effect of vitamin E and/or selenium on reproductive performance of New Zealand and White Baladi black doe rabbit under climate conditions of middle Egypt. Pro. 3rd Afri. Con. Anim. Agri. 11th Con. Egyptian, 6-9.

Meshreky, S. Z., Mervat, M., Arafa, M. A., Abo, W., \& Gad Alla, S. A. Z. (2007). Male and female rabbits performance traits as affected by dietary aflatoxin contamination and its detoxification. Egyptian Journal of Rabbit Science, 17(1), 2742. 
Meshreky, S., \& Shaheed, I. (2003). Efficiency of vitamin E and selenium administration on growth performance, puberty and anatomical and histopathological traits of female genitalia in New Zealand White rabbits. Egyptian J. Nutrition and Feeds, 6 (Special issue), 299, 312.

Moallem, U., Shafran, A., Zachut, M., Dekel, I., Portnick, Y., \& Arieli, A. (2013). Dietary $\alpha$-linolenic acid from flaxseed oil improved folliculogenesis and IVF performance in dairy cows, similar to eicosapentaenoic and docosahexaenoic acids from fish oil. Reproduction, 146(6), 603-614. https://doi.org/10.1530/REP-13-0244

Muzvondiwa, J. V., Kamanda, M. T., Nyamukanza, C. C., \& Mutisi, C. (2011). Effect of protein and energy levels on faecal progesterone concentration in Sabi ewes during oestrus cycle. Livestock Research for Rural Development, 23(5), 2011.

Nuriyasa, I. M., Puspani, E., \& Yupardhi, W. S. (2018). Performance and carcass of local rabbit (Lepus nigricollis) fed concentrate on different levels based on carrot leaf waste (Daucus carota L.). International Journal of Life Sciences, 2(3), 13-19. https://doi.org/10.29332/ijls.v2n3.189

Paris, M. C. J., Andersen, C. Y., \& Shaw, J. M. (2009). Ovarian cryopreservation and grafting: its potential for human reproductive biology and animal conservation. Anim Reprod, 6(1), 96-113.

Parkes, A. S. (1931). The reproductive processes of certain mammals. II.-The size of the Graafian follicle at ovulation. Proceedings of the Royal Society of London. Series B, Containing Papers of a Biological Character, 109(761), 185-196. https://doi.org/10.1098/rspb.1931.0076

Patterson, D. J., Perry, R. C., Kiracofe, G. H., Bellows, R. A., Staigmiller, R. B., \& Corah, L. R. (1992). Management considerations in heifer development and puberty. Journal of Animal Science, 70(12), 4018-4035. https://doi.org/10.2527/1992.70124018x

Petit, H. V., Dewhurst, R. J., Proulx, J. G., Khalid, M., Haresign, W., \& Twagiramungu, H. (2001). Milk production, milk composition, and reproductive function of dairy cows fed different fats. Canadian Journal of Animal Science, 81(2), 263-271. https://doi.org/10.4141/A00-096

Popesko, P., Rajtová, V., \& Horák, J. (1990). A colour Atlas of Anatomy of small laboratory animals, Volume two: rat, mouse, golden hamster.

Rhind, S. M. (1992). Nutrition: its effects on reproductive performance and its hormonal control in female sheep and goats.

Robinson, R. S., Pushpakumara, P. G. A., Cheng, Z., Peters, A. R., Abayasekara, D. R. E., \& Wathes, D. C. (2002). Effects of dietary polyunsaturated fatty acids on ovarian and uterine function in lactating dairy cows. REPRODUCTION-CAMBRIDGE-, 124(1), 119-131.

Rommers, J. M., Meijerhof, R., Noordhuizen, J. P. T. M., \& Kemp, B. (2010). Effect of different feeding levels during rearing and age at first insemination on body development, body composition, and puberty characteristics of rabbit does. World Rabbit Science, 9(3), 101-108.

Ross, M. H., Romrell, L. J., \& Kaye, I. G. (1995). Histology: A Text and Atlas. 3'd edition. Wiiliams and Wilkins. Baltimore, Maryland, USA. pp, 636-658.

Ryan, D. P., Spoon, R. A., \& Williams, G. L. (1992). Ovarian follicular characteristics, embryo recovery, and embryo viability in heifers fed high-fat diets and treated with follicle-stimulating hormone. Journal of animal science, 70(11), 3505-3513. https://doi.org/10.2527/1992.70113505x

Smits, R., \& Australia, R. (2010). Field evaluation of the benefits of fish oil dietary supplementation to multiparous sows fed during lactation and early pregnancy on fertility.

Spies, H. G., Francis Pau, K. Y., \& Yang, S. P. (1997). Coital and estrogen signals: a contrast in the preovulatory neuroendocrine networks of rabbits and rhesus monkeys. Biology of reproduction, 56(2), 310-319. https://doi.org/10.1095/biolreprod56.2.310

Thangavelu, G., Colazo, M. G., Ambrose, D. J., Oba, M., Okine, E. K., \& Dyck, M. K. (2007). Diets enriched in unsaturated fatty acids enhance early embryonic development in lactating Holstein cows. Theriogenology, 68(7), 949-957. https://doi.org/10.1016/j.theriogenology.2007.07.002

Thatcher, W. W., Staples, C. R., Danet-Desnoyers, G., Oldick, B., \& Schmitt, E. P. (1994). Embryo health and mortality in sheep and cattle. Journal of Animal Science, 72(suppl_3), 16-30. https://doi.org/10.2527/1994.72suppl_316x

Veshkini, A., Asadi, H., Khadem, A. A., Mohammadi-Sangcheshmeh, A., Khazabi, S., Aminafshar, M., ... \& Cinar, M. U. (2015). Effect of Linolenic acid during in vitro maturation of ovine oocytes: embryonic developmental potential and mRNA abundances of genes involved in apoptosis. Journal of assisted reproduction and genetics, 32(4), 653-659.

Ermayanti, N. G. A. M., Suaskara, I. B. M., Setyawati, I., Suarni, N. M. R., \& Widhyastini, I. G. A. M. (2019). Effect of cod liver oil supplementation in commercial feed on reproductive organs weight and ovarian follicles size of local rabbits. International Journal of Life Sciences, 3(2), 41-51. https://doi.org/10.29332/ijls.v3n2.309 
Wathes, D. C., Abayasekara, D. R. E., \& Aitken, R. J. (2007). Polyunsaturated fatty acids in male and female reproduction. Biology of reproduction, 77(2), 190-201. https://doi.org/10.1095/biolreprod.107.060558

Wonnacott, K. E., Kwong, W. Y., Hughes, J., Salter, A. M., Lea, R. G., Garnsworthy, P. C., \& Sinclair, K. D. (2010). Dietary omega-3 and-6 polyunsaturated fatty acids affect the composition and development of sheep granulosa cells, oocytes and embryos. Reproduction, 139(1), 57.

Zeleznik, A. J., Leung, P. C. K., \& Adashi, E. Y. (2004). The Ovary.

Zeron, Y., Sklan, D., \& Arav, A. (2002). Effect of polyunsaturated fatty acid supplementation on biophysical parameters and chilling sensitivity of ewe oocytes. Molecular reproduction and development, 61(2), 271-278. https://doi.org/10.1002/mrd.1156

Žitný, J., Massányi, P., Trakovická, A., Rafaj, J., \& Toman, R. (2004). Quantification of the ovarian follicular growth in rabbits. Bull. Vet. Inst. Pulawy, 48, 37-40. 


\section{Biography of Authors}

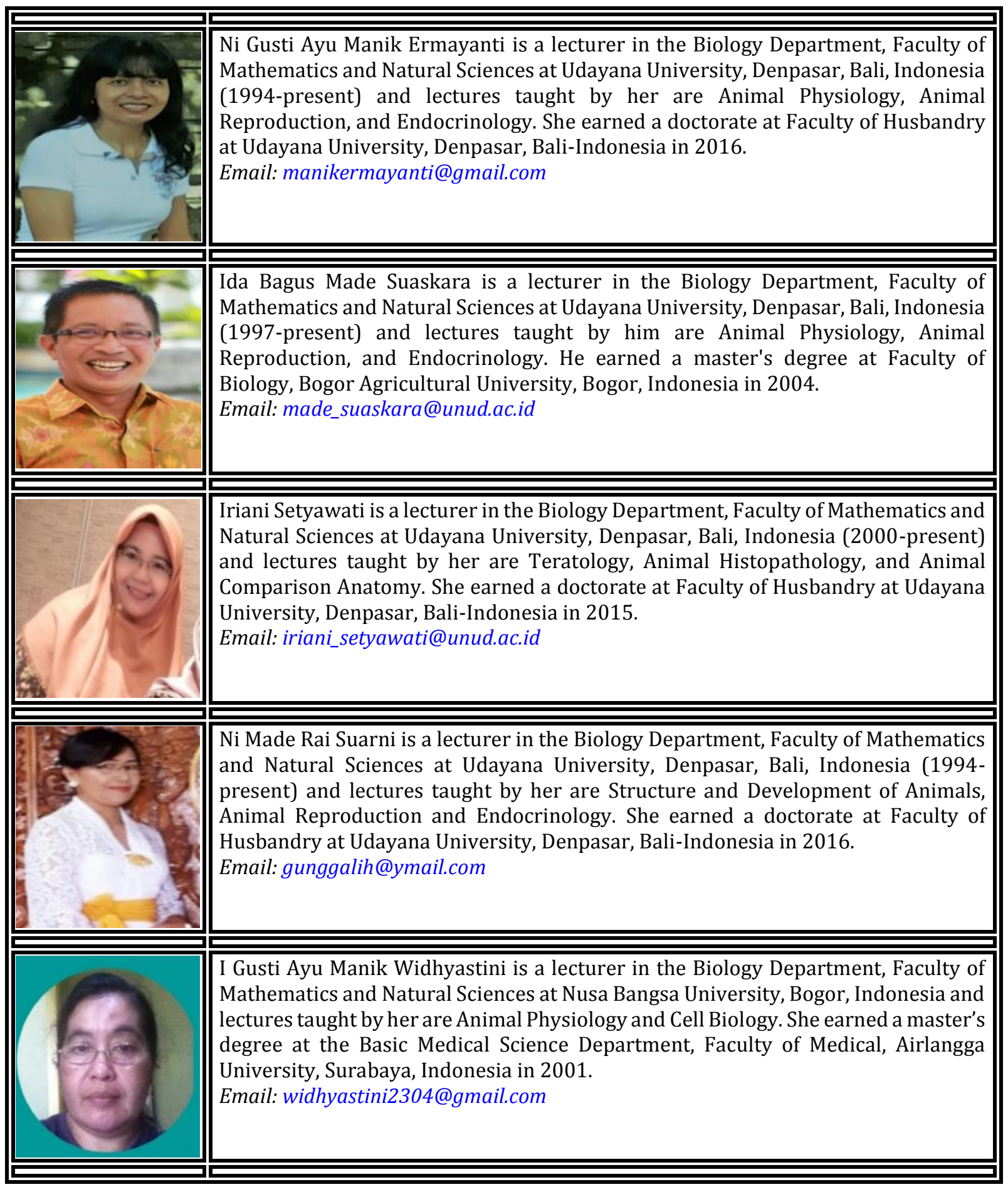

Ermayanti, N. G. A. M., Suaskara, I. B. M., Setyawati, I., Suarni, N. M. R., \& Widhyastini, I. G. A. M. (2019). Effect of cod liver oil supplementation in commercial feed on reproductive organs weight and ovarian follicles size of local rabbits. International Journal of Life Sciences, 3(2), 41-51. https://doi.org/10.29332/ijls.v3n2.309 